\title{
EURYCINOID: POTENSI RUMPUT GONG (EURYCAULON CINEREUM) KHAS BANGKA BELITUNG SEBAGAI KANDIDAT SENYAWA ANTIKANKER PAYUDARA BERBASIS BAHAN ALAM
}

\author{
Dian Nida Salsabila1, Asgar Purnama², Yoga Febriana ${ }^{3}$, Hady Anshory ${ }^{4}$, Arde Toga \\ Nugraha $^{5}$ \\ 1,2,3,4,5 Prodi Farmasi, Fakultas Matematika dan Ilmu Pengetahuan Alam, Universitas Islam \\ Indonesia \\ Yogyakarta
}

\begin{abstract}
Traditionally, some People from bangka belitung has consumed Eriocaulon cinereum $R$.Br as an anticancer drug. Aims of this study is to determine the potential of cytotoxicity of Fraction of Ethyl Acetate and Dichlorometane against T47D cell. Fractionation using Vacuum Liquid Chromatography (VLC) method. MTT assay method was used on evaluating the citotoxic activity. The fraction of dichloromethane performed high activity as a chemopreventive agent with IC50 score was $131,921 \mu \mathrm{g} / \mathrm{ml}$ to T47D and 413,042 $\mu \mathrm{g} / \mathrm{ml}$ cells to vero cell whereas for ethyl acetate fraction performed lower activity as chemopreventive agent with IC50 score was $531,808 \mu \mathrm{g} / \mathrm{ml}$ to T47D and 679,114 $\mu \mathrm{g} / \mathrm{ml}$ to vero cell). Phytochemical tests showed that the dichloromethane fraction contains phenolic, steroid and terpenoid compounds. While ethyl acetate fraction contains alkaloids, flavonoids and terpenoids. These compounds have activity on cancer cells through apoptotic mechanisms. The results showed the excellent potential of this plant in killing breast cancer cells.
\end{abstract}

Keywords: Breast cancer, Eriocaulon cinereum RBr, T47D, Vero

\section{PENDAHULUAN}

Kanker merupakan suatu kondisi yang ditandai adanya pertumbuhan jaringan secara otonom yang tidak mengikuti aturan dan regulasi sel normal (American Cancer Society, 2017). Kanker payudara adalah kanker yang paling umum terjadi pada wanita dan diinduksi oleh lingkungan, genetik, dan faktor risiko epigenetik (Cheuk et al., 2017). Di seluruh dunia, kanker payudara mencakup $25,5 \%$ dari semua jenis kanker pada wanita (Lee et al., 2017). Berdasarkan Pusat Data dan Infomasi Kementrian Kesehatan Republik Indonesia pada tahun 2013 dinyatakan bahwa kanker payudara merupakan salah satu penyakit dengan prevalensi tertinggi setelah kanker serviks di Indonesia, dengan persentase kejadian sebesar $0,5 \%$. Estimasi terbanyak jumlah penderita kanker payudara terdapat pada provinsi Jawa Timur dan Jawa Tengah, sedangkan prevalensi tertinggi kanker payudara di Indonesia adalah di Yogyakarta.

Operasi pembedahan payudara dan mastektomi, merupakan pengobatan definitif untuk penyakit ini. Perawatan adjuvan seperti terapi radiasi, kemoterapi, dan terapi hormonal, diresepkan untuk mengurangi kekambuhan penyakit dan metastasis(Cheuk et al., 2017). Toksisitas dari pengobatan sintesis juga membatasi penggunaan dan efektivitasnya. Oleh karena itu, dibutuhkan terapi alternatif yang efektif terhadap kanker dengan efek samping minimal (Greenwell and Rahman., 2015). Senyawa metabolit tanaman telah menunjukkan karakteristik penghambatan aktivitas sel kanker, seperti menghambat proliferasi sel kanker dan menginduksi apoptosis (Fridlender et al., 2015).

Masyarakat Bangka Belitung di Indonesia menggunakan Eriocaulon 
cinereum R.Br (yang secara tradisional dikenal dengan nama rumput gong) sebagai obat antikanker. Genus Eriocaulon kerap digunakan untuk mencegah pertumbuhan sel yang tidak normal (Fan et al., 2016). Tanaman ini juga diaplikasikan sebagai senyawa pendamping (adjuvan) dalam terapi tumor oleh masyarakat Cina secara turun-temurun (Fan et al., 2016). Penelitian terhadap rumput gong spesies buergerianum yang terdapat di Cina menunjukkan bahwa tanaman tersebut mengandung senyawa flavon dan isoflavon melimpah yang memiliki aktivitas dalam menghambat karsinogenesis (Qiao et al., 2012; Chahar et al., 2011). Studi lain terhadap sel leukimia HL-60 menunjukkan bahwa rumput gong spesies sieboldianum memiliki aktivitas anti kanker melalui induksi apoptosis jalur sinyal mitokondria (Kim et al., 2009).

Pengujian terhadap potensi aktivitas sitotoksik genus Eriocaulon dengan spesies buergerianum menunjukkan bahwa fraksi etil asetat terbukti efektif terhadap sel leukimia K562 (Fan et al., 2016). Penelitian terhadap sel leukimia HL-60 menunjukkan bahwa genus Eriocaulon dari spesies sieboldianum memiliki aktivitas anti kanker melalui induksi apoptosis jalur sinyal mitokondria (Kim et al., 2009). Sedangkan pada salah satu penelitian, diketahui bahwa ekstrak etil asetat $E$. sieboldianum lebih efektif dari pada ekstrak petroleum eter, ekstrak dibromoklorometana dan ekstrak nbutanol, dalam hal aktivitas sitotoksik (Fan et al., 2016). Penelitian pendahuluan terhadap sel HeLa, ekstrak etanol rumput gong (Eriocaulon cinereum) dari Bangka Belitung terbukti aktif sebagai antikanker dengan Inhibition Concentration ( $\left.\mathrm{IC}_{50}\right) \quad 427,79$ $\mu \mathrm{g} / \mathrm{mL}$ (Nugraha, A.T et al., 2017). Penelitian hidayati pada tahun 2017 dari ekstrak etil asetat rumput gong (Eriocaulon cinereum) terhadap kanker serviks memiliki aktivitas dengan Inhibition Concentration ( $\left.\mathrm{IC}_{50}\right) \quad 427,79$ $\mu \mathrm{g} / \mathrm{mL}$ (Hidayati, 2017).

Penelitian lain dari E. buergerianum yang terdapat di Cina pun menunjukkan bahwa tanaman tersebut mengandung senyawa flavon dan isoflavon yang melimpah (Qiao et al., 2012). Kedua senyawa ini termasuk ke dalam golongan flavonoid dan memiliki aktivitas dalam menghambat karsinogenesis (Chahar et al., 2011). Pada penelitian Hidayati ekstrak etil asetat rumput gong (Eriocaulon cinereum) mengandung fenolik, steroid, terpenoid, dan flavanoid. Sedangkan penelitian lainnya dari spesies siebeldanium mengandung senyawa polar isoflavone, flavones dan napthopyranones (Lisna, 2017). Dengan demikian, rumput gong dinilai mempunyai potensi sebagai anti kanker. Namun, data ilmiah mengenai efektivitas dari fraksi rumput gong terhadap sel kanker payudara belum tersedia. Oleh karena itu, penelitian ini bertujuan untuk mengetahui potensi aktivitas sitotoksik fraksi dari ekstrak etil asetat rumput gong pada sel kanker payudara (MCF7). Selain itu, identifikasi senyawa juga perlu dilakukan agar golongan metabolit sekunder yang terdapat di dalam tanaman tersebut dapat diketahui.

\section{METODE PENELITIAN}

Prosedur umum penelitian: Ultrason Assisted Extraction digunakan untuk mempercepat proses maserasi dan proses pemisahan pelarut dengan ekstrak dilakukan dengan Rotary Evaporator. Fraksinasi dilakukan dengan bantuan Vacuum Liquid Chromatography (VLC). Plat Silika GF254 digunakan untuk analisis KLT dan divisualisasikan dengan sinar UV 254 dan 366 dengan lampu. Kemudian dilakukan uji aktivitas sitotoksik dari fraksi yang diperoleh menggunakan ELISA.

Bahan: Eriocaulon cinereum R.Br dideterminasi oleh Ruwati Nurmasari dan dikoleksi pada bulan Januari 2018 dari Bangka Belitung, Indonesia, etil asetat, n-hexan, sel kanker payudara (HeLa), sel normal (sel Vero), PLGA, PVA 2,5\%, media komplit RPMI (Roswell Park Memorial Institute)1640, hepes, fungizon $0,5 \%$, penisilinstreptomisin $1 \%$, sodium bikarbonat, dan FBS (Fetal Bovine Serum) 10\%), SDS (sodium dodecyl sulphate) stopper $10 \%$, MTT 0,5\%, silica gel 60 GF254, pereaksi semprot feri klorida $\left(\mathrm{FeCl}_{3}\right)$, pereaksi aluminium klorida $\left(\mathrm{AlCl}_{3}\right)$, serta pereaksi anisaldehid-asam sulfat, pereaksi semprot sitroborat, pereaksi 
semprot dragendorf, dan pereaksi semprot LB(Liebermann-Burchard), 96well microplates, etanol $70 \%$, media kultur M199, tripsin $0.025 \%$, DMSO (dimethyl sulfoxide, Merck).

Ekstraksi dan Fraksinasi: Simplisia Rumput Gong yang telah dikoleksi kemudian diekstraksi dengan menggunakan Ultrasound Assisted Extraction yang telah dimodifikasi (Nugraha, et al., 2017). Ekstraksi dilakukan menggunakan pelarut $n$ hexana dan etil asetat secara bertingkat dengan suhu $40 \mathrm{C}$ selama 30 menit. Kemudian hasil maserasi disaring kemudian dilakukan pemisahan pelarut dengan filtrate menggunakan rotary evaporator, sampai menghasilkan ekstrak kental. Setelah proses ekstraksi, ekstrak etil asetat rumput gong difraksinasi menggunakan pelarut diklorometan dan etil asetat menggunakan vaccum liquid chromatography (VLC) dengan fase diam berupa silika gel GF254 dan perbandingan fase gerak $n$-heksan:etil asetat.

Uji Fitokimia: Fraksi dari ekstrak etil asetat dan diklorometan rumput gong masing-masing dari hasil fraksinasi dari pelarut stil asetat dan diklorometan dielusi pada plat KLT dengan menggunakan fase gerak berupa campuran n-heksan : etil asetat (3:2). Kemudian divisualisasikan menggunakan sinar UV 254 dan sinar UV 366 setelah disemprotkan dengan pereaksi semprot dragendorf, $\mathrm{FeCl} 3$, $\mathrm{AlCl} 3$, Liebermann Burchard, dan Anisaldehid-Asam Sulfat untuk mengidentifikasi secara kualitatif kandungan senyawa kimia golongan alkaloid, fenolik, flavonoid, steroid, dan terpenoid.

Uji Toksisitas: Sebelum diuji, Sel T47D dan sel Vero dibiakkan dan dipanen terlebih dahulu dalam media media RPMI 1640. Setelah itu baru dilakukan uji sitotoksik menggunakan metode MTT assay. Sebanyak $100 \mu \mathrm{l}$ sel dengan kepadatan $10.000-50.000 \mathrm{sel} / \mathrm{ml}$ diambil, kemudian sel diletakkan ke dalam mikroplate 96-well lalu diinkubasi pada inkubator $\mathrm{CO} 2$ selama 24 jam pada suhu $370 \mathrm{C}$. Sebanyak $100 \mu \mathrm{l}$ sampel dengan berbagai konsentrasi 1000; 500; $250 ; 125 ; 65,5 ; 31,25 ; 15,625$ ppm ditambahkan ke dalam mikroplate kemudian dilakukan inkubasi pada inkubator $\mathrm{CO}_{2}$ selama 24 jam. Sebanyak $100 \mu \mathrm{l} \mathrm{MTT} \mathrm{0,5 \%} \mathrm{ditambahkan} \mathrm{ke} \mathrm{dalam}$ mikroplate, kemudian diinkubasi kembali selama 4 jam pada inkubator CO2. Setelah itu, ditambahkan $100 \mu \mathrm{L}$ SDS stopper (SDS $10 \%$ dalam 0,01 $\mathrm{N} \mathrm{HCl}$ ) dan dilakukan inkubasi pada microplate di suhu ruang selama 24 jam dalam kondisi gelap.Setelah proses inkubasi selesai, sampel digoyangkan selama 5 menit selanjutnya dianalisis menggunakan ELISA reader dengan panjang gelombang $490 \mathrm{~nm}$.

\section{HASIL PENELITIAN}

Sampel yang telah dihaluskan sebanyak 37,5 gram diekstraksi dengan metode Ultrasound Assisted Extration (UAE) secara bertingkat. Pelarut pertama yang digunakan adalah $\mathrm{N}$-heksan sebagai pelarut non polar, selanjutnya ampas diekstrak kembali dengan etil asetat sebagai pelarut semi polar. Dilakukanya ekstraksi secara bertingkat dengan tujuan untuk lebih memisahkan kandungan senyawa rumput gong berdasarkan tingkat kepolarannya. Kemudian Ekstrak etil asetat diuapkan menggunakan rotary evaporator sehingga diperoleh ekstrak kental.

Didapatkan hasil ektrak kental etil asetat seberat 2,522 gram. Ekstrak etil asetat rumput gong kemudian dilakukan perhitungan persen randemen terhadap berat simplisis awal seberat 37,5 gram, sehingga nilai rendemen ekstrak yang dihasilkan sebesar $6,73 \%$. Nilai persen rendemen ini menunjukkan banyak senyawa yang tersari dari proses ekstraksi. Sehingga dapat digunakan untuk memperkirakan jumlah simplisia yang diperukan untuk melakukan ekstraksi selanjutnya. Ekstrak disimpan dalam desikator untuk menjaga stabilitas, kemurnian serta kontaminasi dari bahan lain.

Dari proses fraksinasi didapatkan hasil Fraksi ekstrak etil asetat rumput gong kemudian dilakukan perhitungan persen randemen terhadap berat ekstrak awal seberat 0,35 gram, nilai rendemen untuk fraksi diklorometan sebesar 38,91\% dan etil asetat sebesar $21,43 \%$. Dimana nilai persen rendemen ini menunjukkan banyak senyawa yang tersari dari proses fraksinasi. Sehingga dapat digunakan untuk memperkirakan jumlah 
ekstrak yang diperlukan untuk melakukan fraksinasi selanjutnya. Dari hasil proses fraksinasi fraksi ekstrak etil asetat mengguanakan metode vacuum liquid chromatography (VLC) tidak mendapatkan hasil yang maksimal, dimana pada saat proses elusi analit menggunakan fase gerak, tidak semua analit terelusi secara sempurna yang mana beberapa analit tidak mampu melewati fase diam dan menemel di permukaan fase diam, sehingga hasil yang diperoleh menjadi tidak maksimal. Hal ini bisa terjadi dikarenakan aliran vakum yang digunakan kurang stabil.

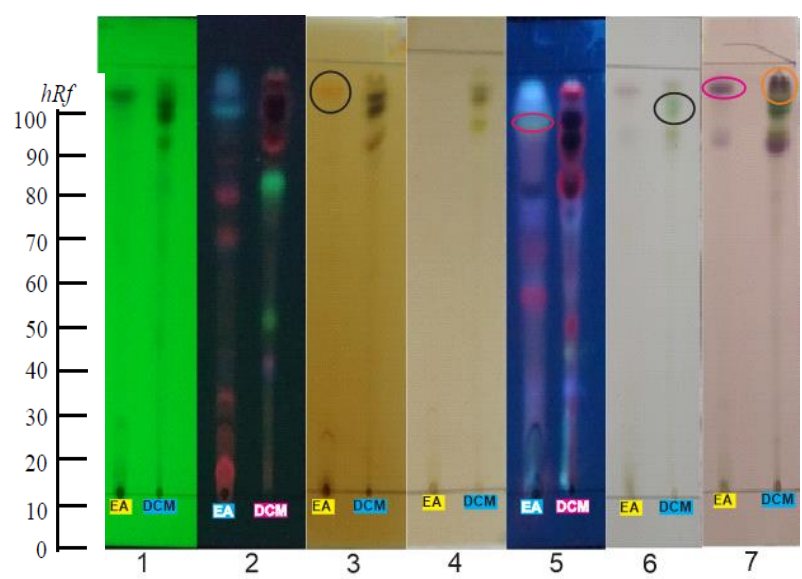

Gambar 4.1. Hasil identifikasi senyawa dengan fase diam silika gel 60 GF254 dan fase gerak n-heksan : etil asetat (3:2)

Keterangan:

$\mathrm{EA}=$ Fraksi Etil asetat, DCM = Diklorometan, (1) Hasil elusi pada $U_{254}$, (2) Hasil elusi pada $U_{366}$, (3) Setelah disemprot dengan pereaksi Dragendorff, (4) Setelah disemprot dengan pereaksi $\mathrm{FeCl}_{3}$, (5) Setelah disemprot dengan pereaksi $\mathrm{AlCl}_{3}$ pada $\mathrm{UV}_{366}$, (6) Setelah disemprot dengan pereaksi LiebermannBurchard, (7) Setelah disemprot dengan pereaksi anisaldehid-asam sulfat. Bagian yang dilingkari pada gambar adalah bercak yang mengalami perubahan warna.

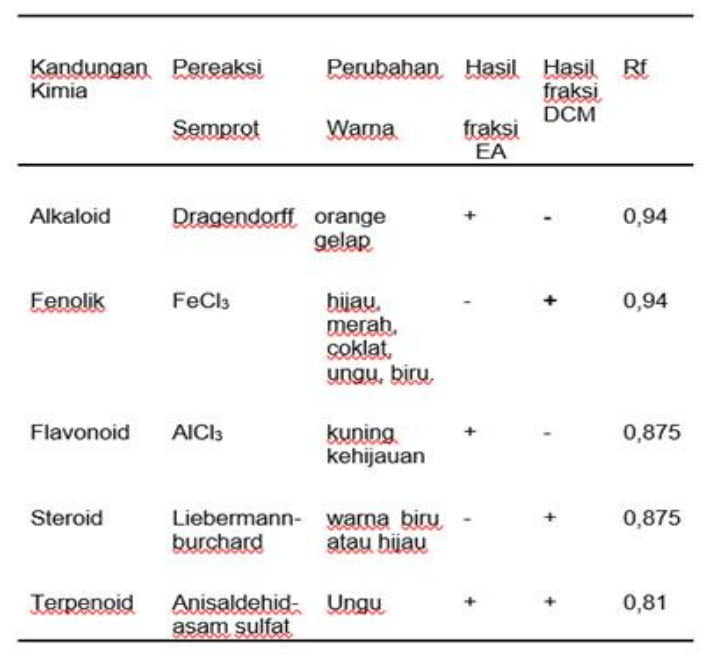

Fraksi dari ekstrak etil asetat tanaman rumput gong dilakukan identifikasi untuk mengetahui golongan senyawa kimia yang terkandung pada fraksi dari ekstrak tersebut. Fraksi diklorometan dan etil asetat ditotolkan pada plat silika gel 60 GF $_{254}$ sebanyak 2 kali dan dielusi menggunakan perbandingan fase gerak n-heksan : etil asetat (3:2) untuk diklorometan dan etil asetat. Selesai dielusi, plat dikeringkan dan diamati pada cahaya tampak, $\mathrm{UV}_{254} \mathrm{~nm}$ dan $U V_{366} \mathrm{~nm}$. Kemudian plat hasil elusi disemprot menggunakan reagen semprot untuk mengidentifikasi golongan senyawa yang ada dalam fraksi tersebut.

Pereaksi dragendorf dikatakan positif mengandung alkaloid apabila memberikan visualisasi cokelat pada sinar tampak dan warna oranye gelap (Gibbons, 2005). Pada penelitian ini, ditemukannya bercak warna orange gelap setelah disemprot dengan pereaksi dragendorff pada fraksi etil asetat yang menunjukkan bahwa fraksi mengandung senyawa alkaloid. Pada penelitian sebelumnya kandungan senyawa alkaloid yaitu, berberin terbukti mampu menghambat proliferasi sel kanker multipel dengan menginduksi penangkapan siklus sel pada $G_{1}$ atau G/M fase dan dengan cara apoptosis dimana nilai $\mathrm{IC}_{50}$ sebesar $10-100 \mu \mathrm{g} / \mathrm{ml}$ dan pada golongan isoflavone terbukti mampu menghambat pertumbuhan pada kanker payudara dengan menghambat apoptosis dimana $\mathrm{IC}_{50}$ sebesar $50 \mu \mathrm{g} / \mathrm{ml}$ (Lu et al., 2012).

$\begin{array}{lll}\text { Pereaksi } \mathrm{FeCl}_{3} \text { dikatakan } & \text { positif } \\ \text { mengandung fenolik } & \text { apabila } \\ \text { memberikan bercak warna merah, }\end{array}$


coklat, hijau,hitam yang kuat, atau biru (Santosa and Haresmita, 2015). Pada penelitian ini terbentuknya warna hijau setelah disemprot dengan pereaksi $\mathrm{FeCl}_{3}$, yang mengindikasikan bahwa adanya kandungan senyawa fenolik dalam fraksi tersebut. Berdasarkan penelitian sebelumnya senyawa elagic acid dimana dilakukan pengujian pada sel kanker colon mampu menghambat pertumbuhan sel kanker dengan cara menghambat apoptosis, dan proliferasi sel kanker (Carocho dan Ferreira, 2013).

Pereaksi $\mathrm{AlCl}_{3}$ dikatakan positif mengandung flavanoid apabila memberikan warna fluoresensi kuning kehijauan di bawah sinarUV 366 (Gibbons, 2005). Hasil pengamatan di bawah sinar $\mathrm{UV}_{366}$ menunjukkan spot tampak berpendar kuning. hal ini menunjukkan bahwa fraksi mengandung senyawa flavonoid. Hal ini sesuai dengan penelitian sebelumya bahwa senyawa golongan flavanoid yaitu, Genistein isoflavon mampu menghambat pertumbuhan sel kanker dengan cara menghambat pertumbuhan epidermal growth factor ( EGF ) dengan nilai $\mathrm{IC}_{50}$ Sebesar $65 \mu \mathrm{g} / \mathrm{ml}$ (Batra dan Sharma, 2013).

Pereaksi semprot Liebermann-Burchard dikatankan positif mengandung steroid apabila memberikan perubahan warna biru atau hijau setelah dilakukan penyemprotan pada plat yang dilakukan pemanasan dalam oven selama 5 menit dalam suhu $100^{\circ} \mathrm{C}$ (Saputri, 2014). Pada penelitian sebelumnya kandungan senyawa Exemestane yang termasuk golongan steroid yang terbukti mampu menghambat pertumbuhan sel kanker dengan induksi apoptosis dan menghambat proliferasi, yang sudah diujikan secara in vitro pada sel kanker payudara dengan nilai $\mathrm{IC}_{50} 42 \mu \mathrm{g} / \mathrm{ml}$ (Gupta et al., 2013).

Pereaksi anisaldehid-asam sulfat dikatakan positif mengandung senyawa terpenoid apabila memberikan perubahan dengan adanya bercak berwarna merah ungu yang terlihat di sinar tampak setelah dilakukan pemanasan dalam oven selama 5 menit dalam suhu $100^{\circ} \mathrm{C}$ (Gibbons, 2005). Hasil pengamatan menunjukkan tampak berwarna ungu, artinya ekstrak etil asetat rumput gong memiliki kandungan senyawa terpenoid. Dari beberapa sebelumnya penelitian telah membuktikan bahwa asam pseudolarik $B$ terbukti mampu menghambat pertumbuhan sel kanker dengan menghambat penetrasi mikrotubulus yang diujikan pada sel kanker payudara (T47D) dengan nilai IC $501 \mu \mathrm{g} / \mathrm{ml}$ (Huang et al., 2012)

Pengujian aktivitas sitotoksik terhadap sel MCF-7 dilakukan dengan MTT Assay yang dapat digunakan untuk mengukur proliferasi sel secara kolorimetri. Reaksi MTT Assay yaitu akan terbentuk violet formazan dari reaksi reduksi senyawa MTT dengan enzim mitokondria reduktase pada sel hidup. Semakin banyak sel yang hidup maka akan menghasilkan nilai absorbansi yang lebih tinggi, sedangkan jika nilai absorbansi kecil menandakan bahwa adanya kematian sel. pembacaan absorbansi dilakukan menggunakan elisa reader pada panjang gelombang $595 \mathrm{~nm}$.

Hasil Uji sitotoksik $\mathrm{IC}_{50}$ yang diperoleh tetap berdasarkan uji probit menggunakan SPSS, data yang diperoleh dibuat kedalam persamaan hubungan antara konsentrasi sebagai $X$ dan persen kematian sel sebagai $Y$. Semakin kecil nilai $I_{50}$ maka semakin kecil konsentrasi yang dibutuhkan suatu fraksi untuk memberikan efek sitotoksik. Uji sitotoksik dilakukan secara in vitro pada sel yaitu dilakukan diluar tubuh inangnya tetapi dibuat suatu lingkungan yang sama dengan kondisi aslinya. pengujian in vitro menggunakan biakan sel (cell line) kanker payudara (MCF-7) dan sel normal (sel vero). Pengujian secara in vitro memiliki kelebihan dibandingkan dengan pengujian secara in vivo yaitu lebih murah, lebih cepat dan membutuhkan lebih sedikit bahan uji (Harahap et al., 2007). Uji secara in vitro secara luas menggantikan pengujian in vivo pada hewan yang mempunyai keterbatasan ketika hasilnya dikorelasikan pada manusia yang berbeda spesies dan karena adanya dukungan moral untuk mengurangi pengujian menggunakan hewan (Sarasmita, 2015). Sel kanker payudara MCF-7 memiliki tingkat angka kejadian yang tinggi, penggunannya pada uji sitotoksik masih jarang dilakukan dan memiliki bentuk terbaik 
dari semua sel kanker payudara pada manusia. Dalam pertumbuhan sel kanker MCF-7 akan membentuk kultur selapis pada tempat tumbuh yang menempel pada culture flask dan media yang sesuai untuk tempat tumbuhnya yaitu dalam medium DMEM (Widowati and Mudahar, 2009). Hasil uji sitotoksik berupa nilai IC50 ditunjukkan pada table berikut :

\begin{tabular}{lll}
\hline \multirow{2}{*}{ Sampel Fraksi } & \multicolumn{2}{l}{$\mathrm{I}_{50}(\mu \mathrm{g} / \mathrm{ml})$} \\
\cline { 2 - 3 } & T47D & Vero \\
\hline Diklorometan & 131,921 & 413,042 \\
Etil Asetat & 531,808 & 679,114 \\
\hline
\end{tabular}

Nilai $I_{50}$ merupakan nilai konsentrasi yang menghasilkan hambatan proliferasi sel $50 \%$ dan menunjukkan potensi ketoksikan suatu senyawa. makin besar nilai $\mathrm{IC}_{50}$, makin rendah potensi suatu senyawa sebagai agen kemopreventif. Nilai IC $50 \leq 20 \mu \mathrm{g} / \mathrm{ml}=$ sangat aktif, $\mathrm{IC}_{50}$ 21-200 $\mu \mathrm{g} / \mathrm{ml}=$ cukup aktif, $\mathrm{IC}_{50} 201$ $500 \mu \mathrm{g} / \mathrm{ml}=$ aktif lemah dan $\mathrm{IC}_{50}>501$ $\mu \mathrm{g} / \mathrm{ml}=$ tidak aktif (Srisawat et al., 2013). Berdasarkan data pada table diatas fraksi diklorometan memiliki aktivitas yang tinggi sebagai agen kemopreventif dengan nilai $I_{50}$ sebesar $131,921 \mu \mathrm{g} / \mathrm{ml}$ terhadap sel T47D dan $413,042 \mu \mathrm{g} / \mathrm{ml}$ terhadap sel normal (Vero) sedangkan untuk fraksi etil asetat memiliki aktifitas yang lebih lemah sebagai agen sitotoksik dengan nilai $\mathrm{IC}_{50}$ sebesar $531,808 \mathrm{ppm}$ terhadap T47D dan 679,114 $\mu \mathrm{g} / \mathrm{ml}$ terhadap sel normal (Vero). Dari hasil tersebut bisa disimpulkan bahwa aktivitas sebagai agen sitotoksik untuk fraksi diklorometan lebih tinggi dibandingakan dengan fraksi etil asetat terhadap sel T47D.

Selektivitas fraksi ekstrak etil asetat rumput gong dievaluasi dengan menggunakan parameter selektivity index (SI). ekstrak dikatakan mempunyai selektivitas yang tinggi apabila nilai $\mathrm{si}=3$, dan dikatakan kurang selektif apabila nilai SI < 3 (Ika rahmawati sutejo et al., 2016).

\begin{tabular}{lll}
\hline \multirow{3}{*}{$\begin{array}{l}\text { Sampel } \\
\text { Fraksi }\end{array}$} & $\begin{array}{l}\text { Selektivita } \\
\text { s Indeks }\end{array}$ \\
\cline { 2 - 3 } & T47D & $\begin{array}{l}\text { Interpretas } \\
\mathbf{i}\end{array}$ \\
\hline Diklorometa & 3,130 & Selektif \\
$\mathrm{n}$ & & $\begin{array}{l}\text { Kurang } \\
\text { Selektif }\end{array}$ \\
Etil Asetat & 1,276 &
\end{tabular}

Hasil analisa selektivitas menunjukkan bahwa fraksi ekstrak etil asetat rumput gong pada fraksi diklorometan menunjukkan selektif karena selektivitas indeksnya melebihi dari 3 yang artinya untuk fraksi diklorometan selektif menghambat sel T47D, sedangkan untuk fraksi dari etil asetat kurang selktif karena selektivitas indeksnya kurang dari 3 dimana artinya agen kemopreventif tidak hanya bisa menghambat sel kanker T47D saja akan tetapi, bisa menghambat pertumbuhan dari sel normal (sel vero).

\section{KESIMPULAN}

Berdasarkan penelitian yang telah dilakukan dapat disimpulkan bahwa rumput gong (Eriocaulon cinereum) sangat berpotensi sebagai kandidat senyawa anti kanker payudara. Dengan adanya penelitian ini, diharapkan kandidat senyawa anti kanker yang telah ditemukan dapat dikembangkan lebih lanjut sebagai agen sitotoksik maupun kemoterapi pada penyakit kanker khususnya kanker payudara.

\section{DAFTAR PUSTAKA}

1. American Cancer Society., 2017. Cancer Facts dan Figurs 2017. atlanta: american cancer society.

2. Chahar, M.K., Sharma, N., Dobhal, M.P., Joshi, Y.C., 2011. Flavonoids: A versatile source of anticancer drugs. Pharmacogn. Rev. 5, 1-12. doi:10.4103/0973-7847.79093

3. Cheuk, I.W.Y., Shin, V.Y., Kwong, A., 2017. Detection of Methylated Circulating DNA as Noninvasive Biomarkers for Breast Cancer Diagnosis. J. Breast Cancer 20, 12. doi:10.4048/jbc.2017.20.1.12

4. Department of Pharmacy, Universities Islam Indonesia, Yogyakarta, Nugraha, A.T., Ramadhan, V., Pandapotan, H., 
Romadhonsyah, F., 2017. A Study of Proliferative Activity of Herbs Eriocaulon Cinereum $\mathrm{RBr}$ on Cervical Cancer Cells (HeLa) with MTT Assay Method. Int. J. Pharma Med. Biol. Sci. 6, 73-76. doi:10.18178/ijpmbs.6.2.73-76

5. Fan, Y., Lu, H., An, L., Wang, C., Zhou, Z., Feng, F., Ma, H., Xu, Y., Zhao, Q., 2016a. Effect of active fraction of Eriocaulon sieboldianum on human leukemia K562 cells via proliferation inhibition, cell cycle arrest and apoptosis induction. Environ. Toxicol. Pharmacol. 43, 13-20. doi:10.1016 /jetap.2015.11.001

6. Fan, Y., Lu, H., An, L., Wang, C., Zhou, Z., Feng, F., Ma, H., Xu, Y., Zhao, Q., 2016b. Effect of active fraction of Eriocaulon sieboldianum on human leukemia K562 cells via proliferation inhibition, cell cycle arrest and apoptosis induction. Environ. Toxicol. Pharmacol. 43, 13-20. doi:10.1016/ jtetap.2015.11.001

7. Fridlender, M., Kapulnik, Y., Koltai, H., 2015. Plant derived substances with anti-cancer activity: from folklore to practice. Front. Plant Sci. 6. doi:10.3389/fpls.2015.00799

8. Greenwell, M., Rahman, P., 2015. Medicinal plants: their use in anticancer treatment. Int. J. Pharm. Sci. Res. 6, 4103.

9. Kim, S.-J., Lee, G.-T., Lee, B.-R., Jeon, K.-S., Rim, H.-K., Bang, J.H., Kim, Y.-G., Myung, N.-Y., Moon, P.-D., Kim, N.-H., Choi, I.-Y., Choi, Y.-J., Kang, I.-C., Um, J.-Y., Hong, S.-H., Kim, H.-M., Jeong, H.-J., 2009. Anti-cancer effect of Eriocaulon sieboldianum through the activation of caspase-3 in human leukemia cell line, HL-60 cells. Orient. Pharm. Exp. Med. 9, 186-191.

doi:10.3742/OPEM.2009.9.2.186

10. Lee, J., Choi, J., Chung, S., Park, J., Kim, J.-E., Sung, H., Han, W., Lee, J.W., Park, S.K., Kim, M.K., Ahn, S.-H., Noh, D.-Y., Yoo, K.-Y., Kang, D., Choi, J.-Y., 2017. Genetic Predisposition of Polymorphisms in HMGB1 -Related Genes to Breast Cancer Prognosis in Korean
Women. J. Breast Cancer 20, 27. doi:10.4048/jbc.2017.20.1.27

11. Qiao, X., Ye, G., Liu, C.-F., Zhang, Z.-X., Tu, Q., Dong, J., Li, Y.-Q., Guo, D.-A., Ye, M., 2012. Chemical analysis of Eriocaulon buergerianum and adulterating species by high-performance liquid chromatography with diode array detection and electrospray ionization tandem mass spectrometry. J. Pharm. Biomed. Anal. 57, 133-142. doi:10.1016 /jjpba.2011.08.033

12. Ika Rahmawati Sutejo, Herwandhani Putri, Edy Meiyanto, 2016. Selektivitas Ekstrak Etanolik Buah Makassar (Brucea javanica) pada Kanker Payudara Metastasis secara In Vitro.

13. Lu, J.-J., Bao, J.-L., Chen, X.-P., Huang, M., Wang, Y.-T., 2012. Alkaloids Isolated from Natural Herbs as the Anticancer Agents. Evid. Based Complement. Alternat. Med. 2012, 1-12.

14. Gupta, A., Sathish Kumar, B., Negi, A.S., 2013. Current status on development of steroids as anticancer agents. J. Steroid Biochem. Molecular. Biol. 137, 242-270.

15. Carocho, M., Ferreira, I., 2013. The role of phenolic compounds in the fight against cancer-a review. AntiCancer Agents Med. Chem. Former. Curr. Med. Chem.-AntiCancer Agents 13, 1236-1258.

16. Santosa, D., Haresmita, P.P., 2015. Antioxidant Activity Determination Garcinia dulcis (Roxb.) Kurz, Blumeamollis (D. Don) Merr., Siegesbeckia orientalis L., and Salvia riparia H.B.K which Collected from Taman Nasional Gunung Merapi Using DPPH (2, 2diphenyl-1-pikril-hidrazil) and Thin Layer Chromatography. Tradit. Med. J. 20, 28-36.

17. Batra, P., Sharma, A.K., 2013. Anticancer potential of flavonoids: recent trends and future perspectives. Biotech 3, 439-459.

18. Gibbons, S., 2005. An introduction to planar chromatography. Natural Product. Iso. 77-116.

19. Jung, Y., Shin, S.Y., Yong, Y., Jung, H., Ahn, S., Lee, Y.H., Lim, 
Y., 2015. Plant-Derived Flavones as Inhibitors of Aurora B Kinase and Their Quantitative StructureActivity Relationships. Chem. Biol. Drug Des. 85, 574-585.

20. Sarasmita A, $2015 . \quad$ Uji Sitotoksisitas Ekstrak Etanol Limbah Kulit Buah Naga Merah (Hylocereus polyrhizus) pada Sel Kanker Payudara Secara Invitro dan In Silico. Journal Farmasi Udayana.
21. Widowati, L., Mudahar, H., 2009. Uji Aktivitas Ekstrak Etanol 50\% Umbi Keladi Tikus (Typhonium Flagelliforme (Lood) BI) Terhadap Sel Kanker Payudara Mcf-7 in Vitro. Media Penelit. Dan Pengemb. Kesehat. 19.

22. Yahdiana Harahap, 1, Nadia Farhanah Syafhan, 1, , 2007. Uji sitotoksisitas sediaan jadi daging buah mahkota dewa (phaleria macrocarpa [scheff.] boerl.) terhadap sel mcf-7 secara in vitro. departement pharmacy 